\title{
Effect of gibberellic acid, B-nine and kinetin on fruit set, parthenocarpy and quality of kyoho grapes
}

\author{
Bhupal Singh, Chundawat*, Eikichi Takahashi and Katsuo Nagasawa \\ Faculty of Horticulture, Chiba University, Matsudo City, Japan
}

\section{Summary}

Healthy vines of Kyoho grapes were selected at the experimental orchard of the Chiba University for the study of effect of gibberellic acid $\left(\mathrm{GA}_{3}\right.$ and $\mathrm{GA}_{4+7}$ ) and kinetin on fruit set, parthenocarpy and quality, and $\mathrm{B}$-nine on vegetative growth, fruit set, yield and quality. $\mathrm{GA}_{3}$ at $50 \mathrm{ppm}, \mathrm{GA}_{4+7}$ at 50,75, and Kinetin at 5,10 , and $20 \mathrm{ppm}$ concentration were applied by dipping the clusters before four days of anthesis and B-nine at 0.5 per cent was applied by spraying at seven node stage of new shoots. Kinetin treatment was completely a failure as all the bunches died after cap fall. Among the GA treatments all the concentrations induced parthenocarpy and increased the yield significantly by increasing the fruit set. However, most effective treatments were $\mathrm{GA}_{3}$ at $50 \mathrm{ppm}, \mathrm{GA}_{4+7}$ at $75 \mathrm{ppm}$ and $100 \mathrm{ppm}$. Their effects on quality were detrimental as they neither reduced the acidity nor increased the total soluble solids percentage as desired and size of the berries was also reduced. B-nine at 0.5 per cent was effective in restricting the vegetative growth by reducing the internodal length and increasing the yield of seeded berries significantly without altering the juice quality and berry size. From the present experiment $\mathrm{GA}_{3}$ at $50 \mathrm{ppm}, \mathrm{GA}_{4+7}$ at $75 \mathrm{ppm}$ and 100 ppm can be recommended for inducing seedlessness and B-nine at 0.5 per cent for increasing yield of berries.

\section{Introduction}

Kyoho, a seeded and vegetatively vigorous hybrid (Vitis vinifera L. $\times$ Vitis labrusca L.), is widely grown in Japan. This variety, when grown under the conditions of volcanic ash soils with heavy rainfall like Chiba prefecture does not bear berries and bunches comparable in size to the ones it produces in Yamanashi and Yamagata prefectures in Japan.

Growth regulators have successfully been used for increasing fruit set in seedless cultivars of grapes (Vitis vinifera L.) in many parts of world ${ }^{2,8,9)}$. Pre-anthesis application of gibberellins, auxins and some growth retardants have been found successful in increasing the set of seeded varieties of grapes ${ }^{3,7,5)}$. Working on Delaware variety of grape, Kishi and Tasaki ${ }^{4)}$ and Clore $^{1)}$ induced parthenocarpic berries by the application of GA before flowering.

The present study was undertaken to investigate the effect of Gibberellins and Kinetin on berry set, berry and bunch weight, total soluble solids, acidity and induction of parthenocarpy in Kyoho variety of grape hybrid under the Chiba conditions. Besides these treatments, Bnine was used to counteract the vigorous vegetative growth and its effect on fruit set, yield and quality of berries was studied.

\section{Materials and Methods}

Vines of Kyoho grape having uniform vigour were selected at the orchard of Faculty of Horticulture, Chiba University in Matsudo city, in 1970. The vines were trained to the Bower system and were pruned in the month of February while they were still dormant. The vines were given uniform fungicidal and insecticidal sprays, irrigation and other cultural practices.

Received for publication January 6, 1971

* Present adress : Jaipur Udyog Ltd., Sawai Madhopur, Rajasthan, India 
Gibberellic acid $\left(\mathrm{GA}_{3}\right) 50 \mathrm{ppm}, \mathrm{GA}_{4+7}\left(\mathrm{GA}_{7} 70 \%\right)(50,75$ and $100 \mathrm{ppm})$, Kinetin (5, 10 and 20 $\mathrm{ppm}$ ) and $\mathrm{B}$-nine at 0.5 per cent were tested in this study. In case of B-nine treatment, five shoots at seven node stage were drenched with B-nine solution of 0.5 per cent concentration and the treatment was replicated four times and five shoots were tagged for control. In case of gibberellin and Kinetin treatments, five randomely selected clusters at pre-aqueous anthesis stage (Just four days before bloom) were dipped momentarily in the appropriate solution containing $100 \mathrm{ppm}$ Aerol-op as a wetting agent. Same treatments of GA and Kinetin were repeated on treated bunches after 15 days of first treatment with the aim of retaining more berries.

The data on fruit set, berry and bunch weight were recorded at the time of harvest. To see the effect of GA, B-nine and Kinetin on the induction of parthenocarpy, seeds were extracted from 25 berries taken at random from each replication and were counted and compared with control berries. The total soluble solids in grape juice were determined with hand refractometer at $20^{\circ} \mathrm{C}$. The acidity was determined by titrating $10 \mathrm{ml}$ of ten times diluted juice against standard sodium hydroxide solution, using phenolphthalein as indicator.

\section{Results and Discussion}

Effect on set. The effect on berry set was elucidated in two forms, as number of inflorescence set into bunches and number of berries per bunch at harvest. These informations are presented in Table 1. As compared to control where only 40 per cent inflorescences set into bunches, GA treatments gave 100 per cent set excepting $\mathrm{GA}_{4+7}$ at $50 \mathrm{ppm}$, where it was only 90 per cent. These informations are in conformation with CoomBE ${ }^{3)}$ where pre-anthesis treatment resulted in increased fruit set in seeded variety of grapes.

Effect of GA treatment on number of berries per bunch was also significantly higher than control. However within GA treatments, there was no significant difference excepting $\mathrm{GA}_{4+7}$ at $50 \mathrm{ppm}$ which was significantly lower than other treatments. Maximum increase of 647.33 per cent over control was obtained in $\mathrm{GA}_{4+7}$ at $100 \mathrm{ppm}$ followed by $\mathrm{GA}_{4+7}$ at $75 \mathrm{ppm}$ and $\mathrm{GA}_{3}$ at $50 \mathrm{ppm}$. These results are in conformation with the work of NiJjar and Bhatia ${ }^{5)}$ in seeded variety of grapes "Anab-e-Shahi”.

In case of B-nine 0.5 per cent spray treatment, the number of inflorescence set into bunches was 60 per cent as compared to 40 per cent in control and the number of berries per bunch were also significantly higher, nearly 294 per cent over control. The most obvious explanation for the increase in set by B-nine treatment is its effect on vegetative growth. This inverse relationship between crop level and shoot growth is in conformation with the relationship reported by $\mathrm{W}_{\text {INKLER }}{ }^{10)}$. Similar increase in berry set of seeded grapes has been reported by CоOмBE $\left.{ }^{2}, 3\right)$ in variety Muscat of Alexandria.

Kinetin dip treatments were completely a failure as all the bunches died just after the cap fall stage. This might be attributed to the unbalance resulted in auxin, gibberellins and kinins. This treatment can further be tested while in combination with gibberellins or by following the kinetin treatment with GA application at cap fall stage.

Effect on weight of bunches and berries. Gibberellic acid $\left(\mathrm{A}_{3}\right)$ at $50 \mathrm{ppm}$ and $\mathrm{GA}_{4+7}$ at 75 and $100 \mathrm{ppm}$ and $\mathrm{B}$-nine at 0.5 per cent resulted in an increased bunch weight (Table 1). $\mathrm{GA}_{4+7}$ 
at $50 \mathrm{ppm}$ was only ineffective in increasing the weight of bunch significantly. Maximum increase of 381.4 per cent over control was obtained in $\mathrm{GA}_{4+7}$ at $100 \mathrm{ppm}$ followed by $\mathrm{GA}_{3}$ at $50 \mathrm{ppm}, \mathrm{GA}_{4+7}$ at $100 \mathrm{ppm}$ and $\mathrm{B}$-nine at 0.5 per cent.

All the GA treatments reduced the berry weight significantly at 1 per cent level. B-nine at 0.5 per cent increased the berry weight but the increase was negligible. Therefore, increase in bunch weight under these treatments is attributed to the number of berries per bunch. Similar increase in bunch weight in seeded varieties of grapes have been reported by СоомвE ${ }^{3)}$, NijJAR and Bhatia ${ }^{5}$. However, NijJar and Bhatia reported increase in berry weight in GA treatments. In present experiment, the decrease in weight might be due to induction of seedlessness which generally results in smaller fruits. All the GA treated bunches were harvested fifteen days earlier as compared with control. However, B-nine did not have any effect on earliness of ripening.

Effect on seedlessness. The results with respect to seedlessness (Table 1) showed that all the GA treatments excepting $\mathrm{GA}_{4+7}$ at $50 \mathrm{ppm}$ resulted in complete seedlessness of parthenocarpy when applied just before anthesis. In case of $\mathrm{GA}_{4+7}$ at $50 \mathrm{ppm}$ the degree of seedlessness was only 95 per cent as compared to other GA treatments where it was 100 per cent. Similarly, CоомвE ${ }^{3)}$ reported the production of seedless berries by GA treatment in Muscat of Alexandria and NiJjar and Bhatia ${ }^{5)}$ in Anab-e-Shahi to the extent of 36 per cent with GA at 100 ppm. The induction of seedlessness by gibberellic acid treatments may be attributed to many factors like abortion of seeds, effect on pollen germination, respiratory activity of pollens as reported in Delaware variety of grapes by Sugiura and INABA $^{6)}$, but these all need to be confirmed under separate investigation in this variety. The B-nine spray did not have any effect on seedlessness as in GA treatments.

Effect on fruit quality. The data on the effect of GA and B-nine on total soluble solids and acidity of grape juice are presented in Table 1 . All GA and B-nine treatments reduced the T.S.S. percentage of juice. However significant decrease was observed only in $\mathrm{GA}_{4+7}$

Table 1. Effect of growth regulators on cropping and quality of Kyoho grape cultivar. (1970)

\begin{tabular}{|c|c|c|c|c|c|c|c|c|}
\hline Treatment & $\begin{array}{c}\text { Bunch } \\
\text { set } \\
(\%)\end{array}$ & $\begin{array}{l}\text { Berry set } \\
\text { per bunch } \\
(\%)\end{array}$ & $\begin{array}{l}\text { Bunch } \\
\text { weight } \\
(\mathrm{g})\end{array}$ & $\begin{array}{l}\text { Berry } \\
\text { weight } \\
(\mathrm{g})\end{array}$ & $\begin{array}{c}\text { T.S. S. } \\
(\%)\end{array}$ & $\begin{array}{c}\text { Acidity } \\
\mathrm{mg} / 100 \mathrm{cc} .\end{array}$ & $\begin{array}{l}\text { T.S.S./ } \\
\text { Acidity } \\
\text { ratio }\end{array}$ & $\begin{array}{l}\text { Degree of } \\
\text { seedlessness }\end{array}$ \\
\hline Control & 40 & 7.5 & 60.50 & 8. 64 & 15.00 & 0.82 & 18. 00 & $100 \%$ seeded \\
\hline $\mathrm{GA}_{3} 50 \mathrm{ppm}$ & $\begin{array}{c}100 \\
(+150)\end{array}$ & $\begin{array}{r}44.40 * * \\
(+492.00)\end{array}$ & $\begin{array}{r}276.90 * * \\
(+357.68)\end{array}$ & $\begin{array}{c}5.75^{* *} \\
(-33.45)\end{array}$ & $\begin{array}{c}14.85 \\
(-1.00)\end{array}$ & $\begin{array}{c}1.12 * * \\
(+36.56)\end{array}$ & $\begin{array}{c}13.29 * * \\
(-26.17)\end{array}$ & $\begin{array}{l}100 \% \\
\text { seedless }\end{array}$ \\
\hline $\begin{array}{l}\mathrm{GA}_{4+7} \\
\quad 50 \mathrm{ppm}\end{array}$ & $\begin{array}{r}90 \\
(+125)\end{array}$ & $\begin{array}{r}25.15^{*} \\
(+235.33)\end{array}$ & $\begin{array}{c}134.81 \\
(+122.82)\end{array}$ & $\begin{array}{c}5.43^{* *} \\
(-37.16)\end{array}$ & $\begin{array}{l}13.20 * * \\
(-12.00)\end{array}$ & $\begin{array}{c}1.12^{* *} \\
(+36.56)\end{array}$ & $\begin{array}{l}11.83 * * \\
(-34.28)\end{array}$ & $\begin{array}{l}95 \% \\
\quad \text { seedless }\end{array}$ \\
\hline $\begin{array}{l}\mathrm{GA}_{4+7} \\
\quad 75 \mathrm{ppm}\end{array}$ & $\begin{array}{c}100 \\
(+150)\end{array}$ & $\begin{array}{r}45.90 * * \\
(+512.00)\end{array}$ & $\begin{array}{r}258.80 * * \\
(+327.76)\end{array}$ & $\begin{array}{c}5.98^{* *} \\
(-30.79)\end{array}$ & $\begin{array}{l}14.15^{* *} \\
(-5.67)\end{array}$ & $\begin{array}{c}1.00 \\
(+21.95)\end{array}$ & $\begin{array}{l}14.19 * * \\
(-21.17)\end{array}$ & $\begin{array}{l}100 \% \\
\quad \text { seedless }\end{array}$ \\
\hline $\begin{array}{l}\mathrm{GA}_{4+i} \\
100 \mathrm{ppm}\end{array}$ & $\begin{array}{c}100 \\
(+150)\end{array}$ & $\begin{array}{r}56.05^{* *} \\
(+647.33)\end{array}$ & $\begin{array}{r}291.25^{* *} \\
(+381.40)\end{array}$ & $\begin{array}{c}5.68^{* * *} \\
(-34.26)\end{array}$ & $\begin{array}{l}14.10^{* *} \\
(-6.00)\end{array}$ & $\begin{array}{c}1.00 \\
(+21.95)\end{array}$ & $\begin{array}{l}14.16 * * \\
(-21.34)\end{array}$ & $\begin{array}{l}100 \% \\
\text { seedless }\end{array}$ \\
\hline B-nine $0.5 \%$ & $\begin{array}{r}60 \\
(+50)\end{array}$ & $\begin{array}{r}29.52^{* *} \\
(+293.60)\end{array}$ & $\begin{array}{c}255.50 * * \\
(+322.39)\end{array}$ & $\begin{array}{r}8.78 \\
(+1.38)\end{array}$ & $\begin{array}{c}14.75 \\
(-1.67)\end{array}$ & $\begin{array}{l}0.82 \\
(-)\end{array}$ & $\begin{array}{c}17.72 \\
(-1.56)\end{array}$ & $100 \%$ seeded \\
\hline $\begin{array}{r}\text { Kinetin }(5,10 \\
\text { and } 20 \mathrm{ppm})\end{array}$ & - & - & - & - & - & - & - & \\
\hline L. S. D. $5 \%$ & & 13. 84 & 98. 34 & 1. 12 & 0.38 & 0.20 & 0.90 & \\
\hline L. S. D. $1 \%$ & & 18. 94 & 134.87 & 1.52 & 0.51 & 0.28 & 1. 22 & \\
\hline
\end{tabular}

Note : Figures within parenthesis represent percentage increase or decrease over control.

** Significant at 1 per cent level, * Significant at 5 per cent level. 

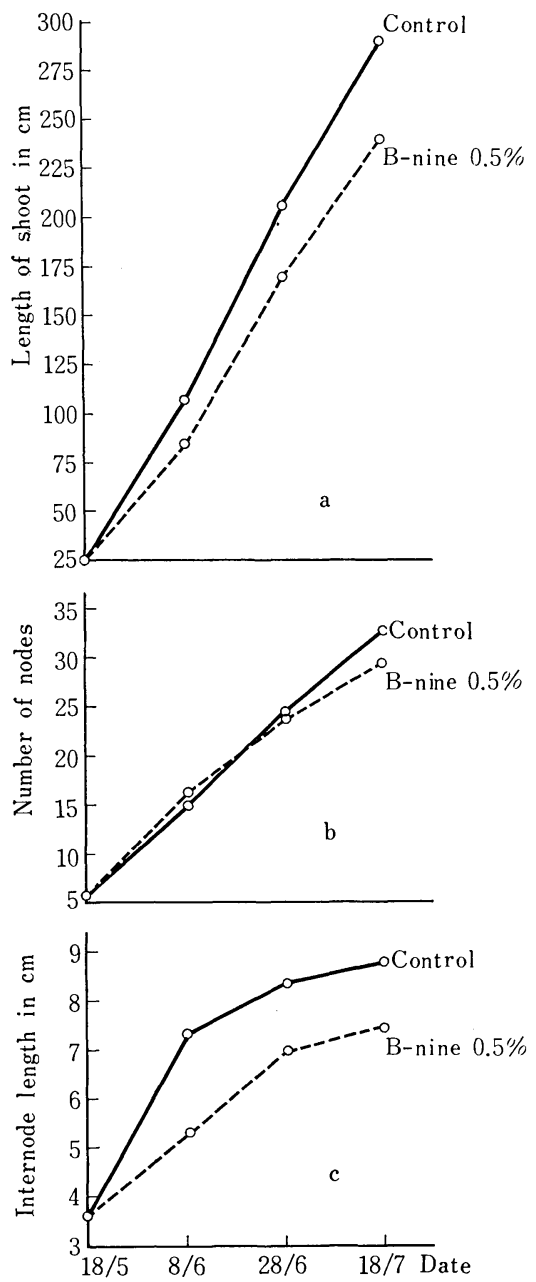

Fig. 1. Effect of $\mathrm{B}$-nine on vegetative growth of Kyoho variety of grape:

a. Shoot length b. Node number

c. Internodal length.

under Chiba conditions. treatments. Maximum decrease of 12 per cent was recorded in $\mathrm{GA}_{4+7}$ at $50 \mathrm{ppm}$.

In contrary to T.S.S., acidity of fruit juice was increased by all the treatments. However, significant increase of 35.56 per cent was only found in $\mathrm{GA}_{3}$ at 50 ppm and $\mathrm{GA}_{4+7}$ at $50 \mathrm{ppm}$. B-nine treatment did not have any effect on acidity.

The reduction in T.S.S. and increase in acidity resulted in low T.S.S./acid ratio signifying the attainment poor fruit quality. It means that all the GA treatments significantly reduced the fruit quality which may be attributed to the earliness of harvest and seedlessness because seed is an important organ for physiological activation of sugar and acid production. B-nine treatment hardly had any effect on quality of berries.

Effect of B-nine on vegetative growth. The effect of $B$-nine on vegetative growth of vines have been compared in Fig. 1. From the figure it is evident that $\mathrm{B}$-nine application has arrested the growth of shoots from the beginning which continued until the harvest. Since the effect on node number was not evident the restriction of growth was mainly due to B-nine's effects on internodal length. Similar effects of growth retardants like CCC on stem growth of vines through their effect on internodal length has been reported by $\mathrm{CoOmBE}^{3)}$. This restriction of vegetative growth of vines made available more of food materials for the fruit to develop and thus resulted in higher set and increased yield and bunch weight of Kyoho grapes. Therefore, B-nine at 0.5 per cent concentration can be recommended as a favorable treatment for increasing yield in Kyoho grapes

\section{Acknowledgement}

The authors are indebted to Ministry of Education Japan for providing financial support as scholarship for $1 \frac{1}{2}$ years and to the staff members of fruit research laboratory of Chiba University for constant criticism and help.

\section{Literature cited}

1. CloRe, W. G. 1965. Response of Delaware grapes to gibberellin. Proc. Amer. Soc. Hort. Sci. $87: 259-63$.

2. Coombe,B.G. 1953. Setting grape by spraying p-CPA. J. Dept. Agric. S. Aust. 57 : 107-10.
3. 1965. Increase in fruit set of Vitis venifera by treatment with growth retardants. Nature $205: 305-6$.

4. KISHI, M. and M. TASAKI. 1958. The effect of gibberellin on grape varieties. Abstract, 
Second Meeting Japan gibberellin Res. Assoc., Tokyo, Japan.

5. NiJjAR, G. S. and G. G. BhatiA 1969. Effect of gibberellic acid and para-chlorophenoxyacetic acid on the cropping and quality of Anab-eShahi grapes. J. Hort. Sci. $44: 91-5$.

6. SugiurA, A. and A. INABA 1968. Studies on the mechanism of gibberellin induced seedlessness of Delaware grapes II. Development of ovules and pollens as affected by pre bloom gibberellin treatment. Memoirs of the college of Agric. Kyoto Univ. No. 93 (Hort. series
No. 4).

7. Venkataratnam, L. 1964. Effect of GA on Anab-e-Shahi grape. Proc. Amer. Soc. Hort Sci. $84: 255-8$.

8. WEAVER, R. J. 1956. Plant growth regulators in grape production. Bull. Calif. Agric. Exp. St. 752 .

9. Weaver, R. J. and Van Overbeak 1963. Kinin stimulate grape growth. J. Calif. Agric. 17: 12. illus.

10. Winkler, A. J. 1945. Pruning vinifera grape vines. Calif. Agric. Exp. Circ. $89: 1-53$.

巨峰の花振い, 単為結果, 品質におよぼすジベレリン, Bナイン, カイネチンの影響

\section{B.S.チュンダワット・高橋英吉・永沢勝雄 \\ (千葉大学園芸学部)}

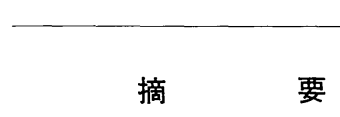

巨峰の花振い防止の目的で, $\mathrm{GA}_{3} 50 \mathrm{ppm} ; \mathrm{GA}_{4+7} 50$, $\mathrm{ppm}$ の各区でその効果が高かつた。

$0.5 \%$ B ナイン散布は新梢の 伸長抑制と有核果の 着生 $70,100 \mathrm{ppm}$; カイネチン $5,10,20 \mathrm{ppm}$ 水溶液の開花 4 日前花房浸漬処理と, Bナイン $0.5 \%$ 水溶液の新梢 7 節 時散布を試みた。

カイネチン処理の花は落花後全部脱落した。GA 処理 花房は無核果を生じ, 花振いの甚しい無処理花房に比し て果房重が大となり, 中でも $\mathrm{GA}_{3} 50 \mathrm{ppm} ; \mathrm{GA}_{4+7} 75,100$ 增加汇きめて効果的で, 果汁の品質, 果粒の大きさ之 もに無処理区のものと変らなからた。

以上の結果から, 巨峰の単為結果の誘起には $\mathrm{GA}_{3} 50$ $\mathrm{ppm} ; \mathrm{GA}_{4+7} 75,100 \mathrm{ppm}$ 処理が，有核果つ増加には $0.5 \%$ B ナイン処理が効果的とい方る。 